\title{
Characterisation of Bosnia and Herzegovina honeys according to their physico-chemical properties during 2016-2017
}

\author{
Jelena Ciric ${ }^{1}$, Drago Sando², Danka Spiric ${ }^{3}$, Jelena Janjic ${ }^{1}$, Marija Boskovic ${ }^{1}$, Milica Glisic ${ }^{1}$, \\ Milan Z. Baltic ${ }^{1}$
}

A b s t $r$ a c t: This study evaluated the quality of 78 honeys of six different floral types (Acacia, sage [Salvia officinalis L.], linden, chestnut, honeydew and blossom), mainly from Bosnia and Herzegovina. Reducing sugars, sucrose content, moisture, hydroxymethylfurfural (HMF), free acidity, water-insoluble content, diastase activity, electrical conductivity were analysed. The samples of honey, collected during 2016-2017, were analysed using recommended methods. Results show that in 2016 and 2017, a great number of individual honeys sampled were of insufficient quality to satisfy regulatory requirements. Among the overall determined parameters, hydroxymethylfurfural and diastase activities in some honeys were not acceptable according to national and international regulations. A correlation between free acidity and electrical conductivity was found in both acacia and blossom honeys. HMF content and diastase activity was strongly negatively correlated in both acacia and blossom honeys. The quality of the honeys was varied, based on botanical origins, and presumably, handling and storage conditions.

Keywords: honey, quality, regulations, physico-chemical parameters.

\section{Introduction}

Honey is a sweet and flavourful natural product produced by honey bees, Apis mellifera, and which is consumed for its high nutritive value and its contribution to consumer health (Habib et al., 2014). The composition of honey is variable and depends on its floral source or botanical origin and geographical region (Ivanovic et al., 2015; Matovic et al., 2018). The quality of honey is mainly determined by physico-chemical and microbiological characteristics. The physico-chemical quality criteria of honey are well specified by the EC Directive 2001/110 (EU, 2002) and national regulations (Official Gazette, 2009; Official Gazette, 2011). The major criteria of interest are moisture content, electrical conductivity, ash, reducing sugars, free acidity, diastase activity and hydroxymethylfurfural (HMF) content (Alvarez-Suarez et al., 2010; Lazarevic et al., 2012). The manipulation of honey (heating) and its possible adulteration is reflected by many of these parameters (Celechovská and Vorlová, 2001; Karabagias et al., 2017). Damage caused by heating can be evidenced by measuring quality control parameters, such as diastase activity and hydroxymethylfurfural (HMF) content (Bodganov et al., 1997; Tosi et al., 2008). HMF is usually absent in fresh and untreated honey (Matovic et al., 2018), but its concentration is reported to increase as a result of heating processes (Fallico et al., 2006) or due to long storage. For this reason, $\mathrm{HMF}$ is a recognized parameter related to the freshness and quality of honey. Also, the activity of diastase is related to its structure, which can be modified by denaturation and heating (Tosi et al., 2008).

Bosnia and Herzegovina produces different types of honey, since honey production is a traditional practice well-implemented in several regions. The detailed characterisation of the different honey types existent in Bosnia and Herzegovina is important, because it will allow the establishment of technical specifications, thus limiting the possibility of adulteration (Grujic and Komic, 2012). Honey quality must be analytically controlled with the aim of guaranteeing its declared specifications. Also, consumers have increasing interest in monofloral honeys (acacia, linden, sunflower etc.) to the detriment

${ }^{1}$ University of Belgrade, Faculty of Veterinary Medicine, Bulevar Oslobodjenja 18, 11000 Belgrade, Republic of Serbia;

${ }^{2}$ Food Safety Agency of BiH, Kneza Viseslava, Mostar 88000, Bosnia and Herzegovina;

3Institute of Meat Hygiene and Technology, Kacanskog 13, 11000 Belgrade, Republic of Serbia.

Corresponding author: Jelena Ciric, 1310jecko@gmail.com 
of multifloral honeys (blossom honey). According to other research, honey has functional properties which promote human health (Giorgi et al., 2011).

The information available on the physico-chemical characteristics of honeys of differing botanical origins produced in Bosnia and Herzegovina is limited. Therefore, the current study was conducted to assess the physico-chemical properties composition of honeys (acacia, sage, linden, chestnut, honeydew and blossom honey) available in Bosnia and Herzegovina during 2016-2017.

\section{Materials and methods}

A total of 78 honeys (nineteen samples of acacia, three samples of sage, eight samples of linden, three samples of chestnut, three samples of honeydew and forty-two samples of blossom honey) collected from different locations in Bosnia and Herzegovina (BiH) (Figure 1) during 2016-2017 were provided by the Food Safety Agency of $\mathrm{BiH}$ (http://www.fsa.gov.ba/fsa/bs/). Among the 78 honeys, 26 were imported (from Serbia or Croatia), while 52 were produced by local beekeepers, but purchased on the retail market. The botanical origin of all honeys was established based on their declarations, sensory characteristics and geographical origins. All honeys were kept in their original packages at $20-21{ }^{\circ} \mathrm{C}$ in the dark before laboratory analysis. Triplicate samples of each honey were then taken to establish physico-chemical parameters.

All physico-chemical parameters of honey were investigated using International Honey Commission (2009) recommended standard methods or official analysis methods from the Association of Official Analytical Chemists $(A O A C, 1990)$. Physico-chemical parameters of honey were evaluated according to the BiH regulation (Official Gazette, 2009; Official Gazette, 2011) and European Council Directive 2001/110/EC (2002). The minimum quality requirements for honey's physico-chemical parameters according to these regulations are presented in Table 1.

The reducing sugar and sucrose contents were analysed following Codex Alimentarius Committee on Codex standard for honey (2001), using HPLC with refractometric detection, with results presented in percent (\%). The moisture content was estimated from the refractive index of all honey samples, using an ABBE refrectometer (CETI, Medline, UK). All measurements were performed at $20^{\circ} \mathrm{C}$, after waiting for $6 \mathrm{~min}$ for equilibrium and results were converted to percent (\%). Electrical conductivity (EC) was determined in a $20 \%(\mathrm{w} / \mathrm{v})$ honey solution using a

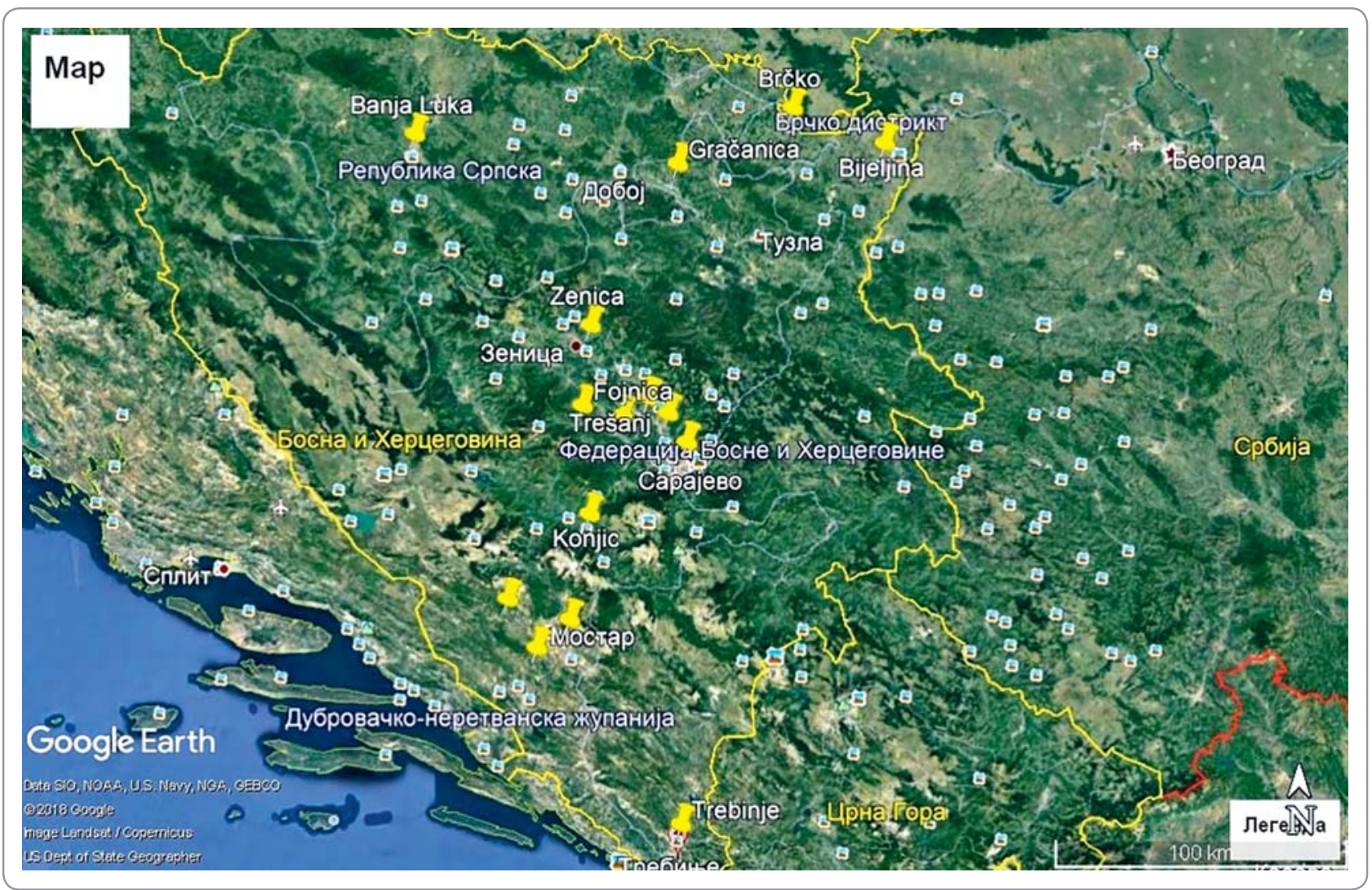

Figure 1. Map of the geographic origins of examined honeys from Bosnia and Herzegovina 
Table 1. Values of physico-chemical parameters for honey, according national and international regulations (Official Gazette, 2009; Official Gazette, 2011; Council Directive 2001/110/EC, 2002)

\begin{tabular}{ll}
\hline Parameter & Criteria* \\
\hline Glucose and fructose content & Blossom honey $60 \leq$ \\
& Honeydew honey, blends of honeydew honey with \\
& blossom honey $45 \% \leq$ \\
Sucrose content & In general: Not more than $5 \%$ \\
Moisture & In general: Not more than $20 \%$ \\
Electrical Conductivity & In general: Not more than 0.8 \\
& mS/cm \\
HMF & In general: Not more than $40 \mathrm{mg} / \mathrm{kg}$ \\
Diastase activities & In general: Not less than 8 \\
Water-insoluble content & In general: Not more than $0.1 \%$ \\
Free acidity & In general: Not more than $50 \mathrm{meq} / \mathrm{kg}$ \\
\hline
\end{tabular}

*The criteria for physico-chemical parameters of honeys of declared origin are presented in detail in regulations (Official Gazette, 2009; Official Gazette, 2011; Council Directive 2001/110/EC, 2002).

conductometer (CyberScan, Thermo Scientific). The method for the determination of EC is described in Bogdanov et al. (1997), and results are presented as $\mathrm{mS} / \mathrm{cm}$. Determination of HMF was by the Winkler method, according to the Harmonised Methods of the European Honey Commission (Bogdanov et al., 1997). A Shimadzu UV-1800 spectrophotometer was used, and results are presented as $\mathrm{mg} / \mathrm{kg}$. Diastase activity was measured according to the Harmonised Methods of the European Honey Commission (Bogdanov et al., 1997), expressed as the diastase number, Schade units. The free acidity was determined by the titrimetric method (using $\mathrm{NaOH}$ and $\mathrm{HCl}$ ). The solution was titrated with $0.05 \mathrm{~N} \mathrm{NaOH}$ at a rate of $5 \mathrm{ml} /$ minute until pH 8.50 was achieved, and results are presented as $\mathrm{mEq} / \mathrm{kg}$. Water-insoluble content was measured by the gravimetric method and is expressed as \% of material insoluble in water. Twenty grams of honey were diluted with water and filtered and washed carefully. The presence of sugars was tested by the addition of $1 \%$ phloroglucinol in ethanol to some filtrate and then a few drops of concentrated sulphuric acid. The crucible was dried at $135^{\circ} \mathrm{C}$ for an hour. The following equation was used (where $\mathrm{m}=$ mass of dried insoluble matter and $\mathrm{m}_{1}=$ mass of honey taken):

Insoluble Matter $(\%)=\mathrm{m} / \mathrm{m}_{1} \times 100$

Analysis of the results was conducted using GraphPad Prism version 7.00 for Windows (GraphPad Software, San Diego, CA, USA, www. graphpad.com). All parameters are described by means \pm standard deviation. Pearson's correlation $(r)$ was used to determine relationships among different physico-chemical parameters.

\section{Results and discussion}

Table 2 illustrates the sugar content (reducing sugar and sucrose contents) of different honeys. The mean reducing sugar content of the examined honeys ranged from $59.57 \pm 12.93 \mathrm{~g} / 100 \mathrm{~g}$ (honeydew) to

Table 2. Reducing sugars and sucrose in honeys $(n=78)$ of differing botanical origins (mean \pm standard deviation)

\begin{tabular}{lcc}
\hline Botanical origin & Reducing Sugars (g/100g) & Sucrose (g/100g) \\
\hline Acacia $(\mathrm{n}=19)$ & $72.26 \pm 6.53$ & $2.55 \pm 1.06$ \\
Sage (Salvia officinalis L.) $(\mathrm{n}=3)$ & $72.80 \pm 2.80$ & $2.63 \pm 1.00$ \\
Linden ( $=8)$ & $73.36 \pm 3.99$ & $2.44 \pm 1.25$ \\
Chestnut (Castanea sativa mill. Fam. Fagacea) $(\mathrm{n}=3)$ & $73.57 \pm 5.62$ & $1.73 \pm 0.45$ \\
Honeydew ( $=3)$ & $59.57 \pm 12.93$ & $2.47 \pm 0.89$ \\
Blossom ( $\mathrm{n}=42)$ & $71.11 \pm 6.20$ & $2.95 \pm 1.51$ \\
\hline
\end{tabular}


Table 3. Moisture content and electrical conductivity of honeys $(n=78)$ of differing botanical origins (mean \pm standard deviation)

\begin{tabular}{lcc}
\hline Botanical origin & Moisture (\%) & $\begin{array}{c}\text { Electrical } \\
\text { Conductivity (mS/ } \\
\text { cm) }\end{array}$ \\
\hline Acacia (n=19) & $16.00 \pm 1.33$ & $0.13 \pm 0.15$ \\
Sage (Salvia officinalis L.) (n=3) & $17.49 \pm 0.28$ & $0.17 \pm 0.10$ \\
Linden ( $\mathrm{n}=8$ ) & $16.71 \pm 0.98$ & $0.16 \pm 0.08$ \\
Chestnut (Castanea sativa mill. Fam. Fagacea) (n=3) & $16.63 \pm 1.00$ & $0.48 \pm 0.19$ \\
Honeydew (n=3) & $15.54 \pm 0.75$ & $0.27 \pm 0.19$ \\
Blossom (n=42) & $16.86 \pm 1.38$ & $0.31 \pm 0.28$ \\
\hline
\end{tabular}

$73.36 \pm 3.99 \mathrm{~g} / 100 \mathrm{~g}$ (chestnut). Reducing sugar levels in all honeys was acceptable according to Codex Alimentarius (2001), except honeydew honey, which had a value $(59.57 \pm 12.93 \mathrm{~g} / 100 \mathrm{~g})$ lower than the Codex limit. El Sohaimy et al. (2015) showed that fructose and glucose are the dominant sugars in honey, and together, they make up the reducing sugars specified in the international standard for honey established by Codex Alimentarius Commission (with a level of not less than $60 \mathrm{~g} / 100 \mathrm{~g}$ ) (Codex Alimentarius, 2001).

The sucrose content of the examined honeys was from $1.73 \pm 0.45 \mathrm{~g} / 100 \mathrm{~g}$ (chestnut) to $2.95 \pm 1.51$ $\mathrm{g} / 100 \mathrm{~g}$ (blossom). All honeys had acceptable sucrose content according to national and international regulations, which state sucrose should be not more than $5 \mathrm{~g} / 100 \mathrm{~g}$ (Codex Alimentarius, 2001).

Several previous studies have been published on the use of physico-chemical parameters for characterisation of honeys from different production regions (Piazza and Persano, 2004, Mărghitaş et al., 2009; Grujic et al., 2011; Grujic and Komic, 2012; Lazarevic et al., 2012; Matovic et al., 2018). As the result of comparing quality characteristics, water content, electrical conductivity and free acidity of honey were the most important parameters for classification of analysed honeys according to their geographical origin. The moisture contents and electrical conductivities of the honeys are presented in Table 3. The moisture content in all honeys indicated a proper degree of maturity, in compliance with the national and international regulations, which state moisture in honey should be not more than 20\% (Official Gazette, 2009; Official Gazette, 2011; Council Directive 2001/110/EC, 2002). This parameter is very important for the shelf life of honey during storage. The moisture contents of Bosnia and Herzegovinian honeys were similar to previously reported moisture levels in other European honeys (Oddo and Piro, 2004; Lazarevic et al., 2012; Grujic and Komic, 2012; Matovic et al., 2018).

The electrical conductivity of the examined honeys is shown in Table 3. The lowest mean electrical conductivity was obtained for acacia honey $(0.13 \pm 0.15 \mathrm{mS} / \mathrm{cm})$ and the highest mean electrical conductivity was measured in chestnut

Table 4. HMF and diastase activity of honeys $(\mathrm{n}=78)$ of differing botanical origins (mean \pm standard deviation)

\begin{tabular}{lcc}
\hline Botanical origin & HMF (mg/kg) & $\begin{array}{c}\text { Diastase activity } \\
\text { (Schade number) }\end{array}$ \\
\hline Acacia ( $\mathrm{n}=19)$ & $31.36 \pm 33.87$ & $10.19 \pm 8.33$ \\
Sage (Salvia officinalis L.) $(\mathrm{n}=3)$ & $44.67 \pm 53.61$ & $11.07 \pm 10.27$ \\
Linden ( $\mathrm{n}=8)$ & $24.25 \pm 16.80$ & $18.86 \pm 10.53$ \\
Chestnut (Castanea sativa mill. Fam. Fagacea) $(\mathrm{n}=3)$ & $32.37 \pm 8.06$ & $14.83 \pm 7.25$ \\
Honeydew ( $\mathrm{n}=3)$ & $18.37 \pm 8.41$ & $12.73 \pm 11.03$ \\
Blossom ( $\mathrm{n}=42)$ & $30.79 \pm 50.68$ & $23.37 \pm 14.35$ \\
\hline
\end{tabular}


Table 5. Water-insoluble content and free acidity of honeys $(n=78)$ of differing botanical origins (mean \pm standard deviation)

\begin{tabular}{lcc}
\hline Botanical origin & $\begin{array}{c}\text { Water-insoluble } \\
\text { content }(\mathbf{g} / \mathbf{1 0 0 g})\end{array}$ & $\begin{array}{c}\text { Free acidity } \\
\text { (mEq/kg) }\end{array}$ \\
\hline Acacia $(\mathrm{n}=19)$ & $0.02 \pm 0.01$ & $12.43 \pm 7.13$ \\
Sage (Salvia officinalis L.) $(\mathrm{n}=3)$ & $0.01 \pm 0.009$ & $15.87 \pm 6.17$ \\
Linden( $=8)$ & $0.46 \pm 1.15$ & $20.40 \pm 6.61$ \\
Chestnut (Castanea sativa mill. Fam. Fagacea) $(\mathrm{n}=3)$ & $0.03 \pm 0.02$ & $16.20 \pm 3.14$ \\
Honeydew (n=3) & $0.03 \pm 0.02$ & $19.03 \pm 12.75$ \\
Blossom $(\mathrm{n}=42)$ & $0.04 \pm 0.07$ & $23.56 \pm 10.49$ \\
\hline
\end{tabular}

honey $(0.48 \pm 0.19 \mathrm{mS} / \mathrm{cm})$. Electrical conductivity is a good criterion for the botanical origin of honey (Adenekan et al., 2010). The honeys from different botanical and geographical origins in Bosnia and Herzegovina were within the standard limit (not more than $0.8 \mathrm{mS} / \mathrm{cm}$ ) (Codex Alimentarius, 2001).

The HMF and diastase activity of honey available in Bosnia and Herzegovina is reported in Table 4. HMF concentrations of honeys ranged from $18.37 \pm 8.41 \mathrm{mg} / \mathrm{kg}$ (honeydew) to $44.67 \pm 53.61 \mathrm{mg} /$ $\mathrm{kg}$ (sage honey). However, HMF concentrations of some samples of acacia, sage, linden, and blossom honey were above the maximum limit of $40 \mathrm{mg} / \mathrm{kg}$ as recommended by European Union (EU Directive 110/2001). The high concentration HMF is reported to have genotoxic effects and mutagenic potential on humans (Janzowski et al., 2000). Several factors have been reported to influence the levels of HMF, such as temperature and time of heating, storage conditions and floral source (Fallico et al., 2006; Anacleto et al., 2009; Vranic et al., 2017; Matovic et al., 2018). Also, previous studies on HMF in honey have reported a considerable increase in its concentration when honey is stored at room temperature (Khalil et al., 2010). Turhan (2009) demonstrated that honey should be consumed within six months of harvesting.

The mean diastase activities of the honeys were from $10.19 \pm 8.33$ (acacia) to $23.37 \pm 14.35$ Schade units (blossom). The current law stipulates a minimum value of 8.00 Schade units (EU Directive 110/2001). Same samples of all our honeys were less than than 8 Schade units. Similar to HMF content, the activity of diastase can be used as an indicator of heating, if the honey has been subjected to heating above $60^{\circ} \mathrm{C}$ (Matovic et al., 2018). Tosi et al. (2008) showed that diastase activity loss occurred as temperature increases, and decrease in diastase activity was more evident at higher rates of temperature increase.

Table 5 shows the water-insoluble content and free acidity of our honeys. The honeys analysed had water-insoluble contents ranging from $0.01 \pm 0.009 \mathrm{~g} / 100 \mathrm{~g}$ (sage honey) to $0.46 \pm 1.15 \mathrm{~g} / 100 \mathrm{~g}$ (linden honey). Acacia, sage, chestnut, honeydew and blossom honeys had the greatest water-insoluble contents. Linden honey had values higher than the maximum limit of water-insoluble contents allowed by BiH legislation $(0.1 \mathrm{~g} / 100 \mathrm{~g})$ (Official Gazette, 2009; Official Gazette, 2011). This physico-chemical

Table 6. Correlations (Pearson's correlation coefficients $-r$ ) between physico-chemical parameters of acacia honey

\begin{tabular}{lccccc}
\hline Parameter & Free Acidity & $\begin{array}{c}\text { Electrical } \\
\text { Conductivity }\end{array}$ & Moisture & HMF & $\begin{array}{c}\text { Diastase } \\
\text { activity }\end{array}$ \\
\hline Free Acidity & - & $0.65^{* *}$ & -0.034 & 0.19 & 0.186 \\
$\begin{array}{l}\text { Electrical } \\
\text { Conductivity }\end{array}$ & - & - & -0.08 & -0.12 & $0.509^{*}$ \\
Moisture & - & - & - & -0.33 & 0.226 \\
HMF & - & - & - & - & $-0.594^{* *}$ \\
\hline
\end{tabular}

$* P<0.05 ; * * P<0.01$ 
Table 7. Correlations (Pearson's correlation coefficients $-r$ ) between physico-chemical parameters of blossom honey

\begin{tabular}{lccccc}
\hline Parameter & Free Acidity & $\begin{array}{c}\text { Electrical } \\
\text { Conductivity }\end{array}$ & Moisture & HMF & $\begin{array}{c}\text { Diastase } \\
\text { activity }\end{array}$ \\
\hline Free Acidity & - & $0.50^{* * *}$ & 0.28 & -0.06 & 0.373 \\
Electrical & - & - & -0.01 & -0.25 & $0.564^{* * *}$ \\
Conductivity & - & - & - & -0.16 & 0.122 \\
Moisture & - & - & - & - & $-0.384^{*}$ \\
HMF & - & & &
\end{tabular}

$* P<0.05 ; * * * P<0.001$

parameter was used when a significant portion of the honey collected was harvested by pressing the combs. However, nowadays, almost all commercial honey is harvested by centrifugation, although wax is a major source of water-insoluble contamination (Bogdanov et al., 1997; Liberato et al., 2013). Similar results for the water-insoluble content in honey were reported in a study of acacia and linden honeys in Serbia (Vranic et al., 2017; Matovic et al., 2018).

The mean free acidity values of honey ranged from $12.43 \pm 7.13 \mathrm{mEq} / \mathrm{kg}$ (acacia) to $23.56 \pm 10.49 \mathrm{mEq} / \mathrm{kg}$ for blossom honey. Free acidity values of all examined honeys were below the legal limit (lower than $50 \mathrm{meq} / \mathrm{kg}$ ), and concord with results presented in other studies (Lazarevic et al., 2012; Vranic et al., 2017; Matovic et al., 2018). Free acidity is an important parameter for honey. Higher values for free acidity can be indicative of fermentation of sugars into organic acids and is related to the deterioration of honey. The variation in free acidity among different honeys can be explained by their diverse botanical origins, the presence of different organic acids, and differing geographical origins or harvest season (da Silva et al., 2016).

Correlations between different physico-chemical parameters of acacia and blossom honeys are presented in Tables 6 and 7, respectively. The regression analysis clearly indicated that free acidity content in honeys significantly correlated with electrical conductivity. Khalil et al. (2010) showed that storage duration, free acid, total acidity, $\mathrm{pH}$ and lactone levels significantly correlated with HMF concentration in honey. The positive correlation between diastase activity and moisture content can be explained by the increase of the enzyme activity in water. Similar results were found by Gomes et al. (2010). HMF content was strongly negatively correlated with diastase activity in acacia honey $(\mathrm{r}=-0.594)$. Therefore, those two parameters are inversely proportionate to each other. This is in agreement with other studies (Thrasyvoulou, 1986; Sahinler and Gul, 2005; Kędzierska-Matysek et al., 2016).

A positive correlation occurred between free acidity and electrical conductivity in blossom honey $(\mathrm{r}=0.50 ; P<0.001)$. A weak correlation was also found between free acidity and moisture content $(\mathrm{r}=0.28)$ in blossom honey (Table 7). Therefore data from both honeys (acacia and blossom) combined with statistical analysis indicate that free acidity and electrical conductivity could provide ways to assess honey quality. Similar results were presented by Khalil et al. (2010) and Celechovská and Vorlová (2001). The HMF was negatively correlated with moisture content $(\mathrm{r}=-0.16)$. This is in agreement with Meda et al. (2005). A significant negative correlation was found between $\mathrm{HMF}$ and diastase activity in blossom honey $(\mathrm{r}=-0.384 ; P<0.05)$.

\section{Conclusion}

Results show that in 2016 and 2017, a great number of honeys in Bosnia and Herzegovina were of insufficient quality to satisfy regulatory requirements. In the future, the quality of honey will need to be monitored in order to improve its quality over the whole territory of Bosnia and Herzegovina.

Acknowledgment: This paper was supported by the Ministry of Education, Science and Technological Development of the Republic of Serbia, Project "Selected biological hazards to the safety/quality of food of animal origin and the control measures from farm to consumer" (31034).

Disclosure Statement: No potential conflict of interest was reported by the authors. 


\section{References}

Adenekan, M. O., Amusa, N. A., Lawal, A. O. \& Okpeze, V. E. (2010). Physico-chemical and microbiological properties of honey samples obtained from Ibadan. Journal of Microbiology and Antimicrobials, 2(8), 100-104.

Alvarez-Suarez, J. M., Tulipani, S., Díaz, D., Estevez, Y., Romandini, S., Giampieri, F. \& Battino, M. (2010). Antioxidant and antimicrobial capacity of several monofloral Cuban honeys and their correlation with color, polyphenol content and other chemical compounds. Food and Chemical Toxicology, 48(8-9). 2490-2499.

Anacleto, D. A., Souza, B. A., Marchini, L. C. \& Moreti, A. C. (2009). Composicao de amostras de mel de abelha Jata1 (Tetragonisca angustula latreille, 1811). Ciencia e Tecnologia de Alimentos, 29, 535-541.

AOAC. (1990). Official Methods of Analysis. $15^{\text {th }}$ edn. Pp. 770 771. Virginia, USA: Association of Official Analytical Chemists, Inc.

Bogdanov, S., Martin, P., Lüllmann, C., Borneck, R., Flamini, C., Morlot, M., Heretier, J., Vorwohl, G., Russmann, H., Persano-Oddo, L., Sabatini, A. G., Marcazzan, G. L., Marioleas, P., Tsigouri, K., Kerkvliet, J., Ortiz, A. \& Ivanov, T. (1997) Harmonised methods of the European honey commission. Apidologie (extra issue), 1-59.

Celechovská, O. \& Vorlova, L. (2001). Groups of honey-physicochemical properties and heavy metals. Acta Veterinaria Brno, 70(1), 91-95.

Codex Alimentarius. (2001). Revised Codex standard for honey. Codex Stan 12-1982: Rev.1 (1987)., Rev. 2, 2001. www.fao.org/docrep/w0076e/w0076e30.htm

Council Directive 2001/110/EC. (2002). Official Journal of the European Communities, 10, 51-52.

da Silva, P. M., Gauche, C., Gonzaga, L. V., Costa, A. C. O. \& Fett, R. (2016). Honey: Chemical composition, stability and authenticity. Food Chemistry, 196, 309-323.

EI Sohaimy, S. A., Masry, S. H. D. \& Shehata, M. G. (2015). Physicochemical characteristics of honey from different origins. Annals of Agricultural Sciences, 60(2), 279-287.

Fallico, B., Arena, E., Verzera, A. \& Zappala, M. (2006). The European Food Legislation and its impact on honey sector. Accreditation and Quality Assurance, 11, 49-54.

Giorgi, A., Madeo, M., Baumgartner, J. \& Lozzia, G. C. (2011). The relationships between phenolic content, pollen diversity, physicochemical information and radical scavenging activity in honey. Molecules, 16(1), 336-347.

Gomes, S., Dias, L. G., Moreira, L. L., Rodrigues, P. \& Estevinho, L. (2010). Physicochemical, microbiological and antimicrobial properties of commercial honeys from Portugal. Food and Chemical Toxicology, 48(2), 544-548.

Grujic, S. \& Komic, J. (2012). Classification of honeys from three geographical regions based on their quality control data. Quality of life, 5 (1-2).

Grujic, S., Grujic, R., Popov-Raljic J. \& Komic, J. (2011). Characterization of Black Locust (Robinia pseudoacacia) honey from three geographical regions of North-West Bosnia and Herzegovina. Proceedings. $7^{\text {th }}$ International Congress of Food Technologists, Biotechnologists and Nutritionists, (pp.). Opatija, Croatia, 274-278.
Habib, H. M., Al Meqbali, F. T., Kamal, H., Souka, U. D. \& Ibrahim, W. H. (2014). Physicochemical and biochemical properties of honeys from arid regions. Food Chemistry, 153, 35-43.

International Honey Commission (2009) Harmonised Methods of the International Honey Commission www. bee-hexagon.net/en/network.htm.

Ivanovic, J., Baltic, M. Z., Jelic, D., Janjic, J., Boskovic, M., Markovic, R. \& Starcevic-Dokmanovic, M. (2015). Research of production volume and market turnover of honey from 2004 to 2014. Veterinarski Glasnik, 69(5-6), 467-478.

Janzowski, C., Glaab, V., Samimi, E., Schlatter, J. \& Eisenbrand, G. (2000). 5-Hydroxymethylfurfural: assessment of mutagenicity, DNA-damaging potential and reactivity towards cellular glutathione. Food and Chemical Toxicology, 38(9), 801-809.

Karabagias, V. K., Karabagias, I. K. \& Gatzias, I. (2017). The impact of different heating temperatures on physicochemical, color attributes, and antioxidant activity parameters of Greek honeys. Journal of Food Process Engineering. DOI: 10.1111/jfpe.12668.

Kędzierska-Matysek, M., Florek, M., Wolanciuk, A., Skałecki, P. \& Litwińczuk, A. (2016). Characterisation of viscosity, colour, 5-hydroxymethylfurfural content and diastase activity in raw rape honey (Brassica napus) at different temperatures. Journal of Food Science and Technology, 53(4), 2092-2098.

Khalil, M. I., Sulaiman, S. A. \& Gan, S. H. (2010). High 5-hydroxymethylfurfural concentrations are found in Malaysian honey samples stored for more than one year. Food and Chemical Toxicology, 48(8-9), 2388-2392.

Lazarevic, K. B., Andric, F., Trifkovic, J., Tesic, Z. \& Milojkovic-Opsenica, D. (2012). Characterisation of Serbian unifloral honeys according to their physicochemical parameters. Food Chemistry, 132(4), 2060-2064.

Liberato, M. D. C. T. C., Morais, S. M. D., Magalhães, C. E. D. C., Magalhães, I. L., Cavalcanti, D. B. \& Silva, M. M. D. O. (2013). Physicochemical properties and mineral and protein content of honey samples from Ceará State, Northeastern Brazil. Food Science and Technology (Campinas), 33(1), 38-46.

Mărghitaş, L. A., Daniel, D., Moise, A., Bobis, O., Laslo, L. \& Bogdanov, S. (2009). Physico-chemical and bioactive properties of different floral origin honeys from Romania. Food Chemistry, 112(4), 863-867.

Matovic, K., Ciric, J., Kaljevic, V., Nedic, N., Jevtic, G., Vaskovic, N. \& Baltic Z. M. (2018). Physico-chemical parameters and microbiological status of honey produced in an urban environment in Serbia. Environmental Science and Pollution Research. DOI: 10.1007/s11356-018-1659-1.

Meda, A., Lamien, C. E., Millogo, J., Romito, M. \& Nacoulma, O. G. (2005). Physiochemical analyses of Burkina Fasan honey. Acta Veterinaria Brno, 74(1), 147-152.

Oddo, L. \& Piro, P. (2004). Main European unifloral honeys: descriptive sheets. Apidologie, 35, 38-81.

Official Gazette. (2009). Bosnia and Herzegovina. Pravilnik o medu i drugim pcelinjim proizvodima i Pravilnik o metodama za kontrolu meda i drugih pcelinjih proizvoda. No. 37, 222. 
Official Gazette. (2011). Bosnia and Herzegovina. Pravilnik o izmjenama i dopunama pravilnika o medu i drugim pcelinjim proizvodima. No. 25, 90.

Piazza, M. G. \& Persano Oddo, L. (2004). Bibliographical review of the main European unifloral Honeys. Apidologie $35,94-111$.

Sahinler, N. \& Gul, A. (2005). Effect of heating and storage on honey hydroxy methylfurfural and diastase activity. Journal of Food Technology, 3, 152-157.

Thrasyvoulou, A. T. (1986). The use of HMF and diastase as criteria of quality of Greek honey. Journal of Apicultural Research, 25(3), 186-195.

Paper received: 8.03.2018.

Paper corrected: 9.05.2018.

Paper accepted: 14.05.2018.
Tosi, E., Martinet, R., Ortega, M., Lucero, H. \& Ré, E. (2008). Honey diastase activity modified by heating. Food Chemistry, 106(3), 883-887.

Turhan, K. (2009). Effects of thermal treatment and storage on hydroxymethylfurfural (HMF) content and diastase activity of honeys collected from middle Anatolia in Turkey. In Innovations in Chemical Biology, Springer, Dordrecht, 233-239.

Vranic, D., Petronijevic, R., Stojanovic, J. Dj., Koricanac, V., Milijasevic, J. B. \& Milijasevic, M. (2017). Physicochemical properties of honey from Serbia in the period 2014-2016. In IOP Conference Series: Earth and Environmental Science, IOP Publishing, 85, 1, 012058. 